\title{
Civilian Resistance in the Security and Defense System of Lithuania: History and Prospects
}

\begin{abstract}
Lithuania is one of the few states in the world whose security and defence strategy assigns an important role to civilian resistance (civilian defence) in addition to the usual military defence. This paper explores the historical circumstances and theoretical presuppositions that have influenced the focussing of Lithuania's political elite on this nontraditional form of defence. First, there is a short survey of the development of the theory of civilian defence and an overview of the way some of its elements have been applied in Lithuania's movement for liberation in 1990-91. Next, there is an analysis of the way civilian resistance and civilian defence are conceived in the documents defining Lithuania's security and defence policies.

Finally, an attempt is made at identifying the role and the prospects of civilian resistance within contemporary security and defence system of Lithuania; the conclusion made is that under conditions of Euro-Atlantic integration and globalization, civilian resistance, as a way of defending civil rights, remains a viable option of response to any kind of threat.
\end{abstract}

\section{Introduction}

Lithuanian National Security Strategy states: "State's defence consists of military security and civilian resistance" ${ }^{1}$. The document explains that civilian resistance comprises both armed (guerrilla warfare) and un-armed (civilian defence) forms of resistance, both to be used in case of foreign occupation. Civilian resistance, as a spontaneous involvement of the civilian population in state defence, is well known and widely documented in various historical sources. However, the advanced incorporation of its potential into the state defence strategy is something quite rare. The two prominent contemporary examples of such incorporation seem to be the concepts of total defence adopted by Switzerland and Sweden.

\footnotetext{
* Doc. dr. Gražina Miniotaite - Associated professor of the Political Science Deparment of the Lithuanian Military Academy; Researcher of the Lithuanian Institute of Culture, Philosophy and Art. Address: Šilo 5a, LT-2055 Vilnius, Lithuania tel. +370-5-2127970, e-mail: grazinam@ktl.mii.lt ${ }^{1}$ Nacionalinio saugumo strategija 2002, 5.2.3.2. [National Security Strategy]. http://www.kam.lt/ catalog/ministerija/nacionalinio_saugumo_strategija_06_05.doc, last viewed 3 September 2003.
} 
In attempting to find elbow room for civilian resistance in the broad spectrum of security conceptualizations, one becomes aware of the theoretical indefiniteness of the idea and of the lack of consistency in its conceptual groundings. One wonders whether civilian resistance can be treated as an independent alternative form of defense or be seen rather as a supplement of military defence. What is the relation between military defence and civilian resistance? Is armed guerilla warfare strategically compatible with various forms of un-armed resistance? Some answers to these questions are provided by the theories of non-provocative defence ${ }^{2}$ and civilian defence. A shared feature of the two theories is that the peak of their popularity belongs to the Cold War period. Both were the expression of an effort to find alternative, non-provocative forms of defence and both focused on strengthening common security and boosting up trust among the states ${ }^{3}$.

The doctrines of non-provocative defence are based on the neo-realist interpretation of the security dilemma. ${ }^{4}$ As Robert Jervis has pointed out, in the anarchic international system a country's armament, even if undertaken for defensive reasons, can be interpreted as armament for offensive reasons, thus triggering retaliatory actions. So, in order to escape the destabilizing effects of the security dilemma it is reasonable to develop a nonprovocative, manifestly defensive security system. ${ }^{5}$ The theory of non-provocative defence is associated with the ideas of collective security, peace keeping, and confidence building. The idea of non-provocative defence seemed particularly potent in early 1990s. However, as the diminishing flow of publications indicates, the interest in it is now gradually waning ${ }^{6}$.

Civilian defence can be treated as a specific case of non-provocative defen$\mathrm{ce}^{7}$. The concept of civilian defence is close to such scholarly concepts as social defence, non-violent defence, civilian-based defence, and defence by civil resistance ${ }^{8}$. These virtually similar concepts are used to conceptualise a particular type of the state defence, the basic principle of which is the capability of people to prevent threats to their fundamental freedoms with non-violent methods ${ }^{9}$. This is not territorial defence, but defence of the most important social values (freedom, independence, democracy, peace) and the social structure which supports these values ${ }^{10}$.

\footnotetext{
${ }^{2}$ Non-provocative defence is close to such concepts as defensive defence, non-offensive defence, territorial defence, defensive deterrence, conventional deterrence and alternative defence. See: Wiseman G., Concepts of Non-provocative Defence: Ideas and practices in international security, New York: Palgrave, 2002, p.3-4; Moller B., Dictionary of Alternative Defence, Boulder, CO: Lynne Rienner, 1995. ${ }^{3}$ The development of the ideas of non-provocative defense was significantly boosted by the activities of the Independent Commission on Disarmament and Security Issues (1982), headed by Sweden's prime minister Olof Palme.

${ }^{4}$ See: Moller B., Common security and Nonoffensive Defense: A Neorealist Perspective, Boulder, CO: Lynne Rienner, 1992.

${ }^{5}$ Jervis R., Perception and Misperception in International Politics, Princeton, NJ: Princeton University Press, 1976, p.64-65.

${ }^{6}$ Though much debated and enjoying public support, the idea of non-provocative defence had not become part of the mainstream strategic thinking even at the peak of its popularity. Its advocates were associated with peace studies rather than with the prestigious strategic studies, and they were mostly voicing the views of the opposition and not of those in power.

${ }^{7}$ Žr.:Wiseman, p.10 (note 2).

${ }^{8}$ See: Brian M., „Social Defence Strategy: the Role of Technology“, Journal of Peace Research, 5 (26), 1999, p. 535-552.

${ }^{9}$ Seе Низинг Й., Общественная оборона как логическая альтернатива, Москва: CЕРСО, 1993, p. 146 (Niezing J., Sociale verdegiging als logisch alternatief, Antwerpen - Assen / Maastricht, 1987).

${ }^{10}$ Geeraerts, G. 1976: Two approaches to civilian defence. In G. Geeraerts (ed.), Possibilities of Civilian Defence in Western Europe. Amsterdam: Swets \& Zeitlinger, p.6.
} 
The concept of civilian resistance comprises the elements of both the doctrine of non-provocative territorial defence and that of civilian defence. This accounts for some inconsistencies engendered by the attempt to merge the positivist realist understanding of international relations with Gandhian normativism. ${ }^{11}$ In fact, both the development and the justification of the concept of civilian resistance have more affinities with the concept of civilian defence rather than that of non-provocative defence. The doctrine of non-provocative defence, focused on the analysis of military defence, is mainly concerned with the mitigation of the security dilemma, while the theorists of civilian defence are primarily interested in the potential of the civilian population's involvement in state defence. In this paper we have relied mainly on the insights of the latter.

The idea to use the civilian resistance in state defence emerged after World War I in the Netherlands among military veterans. This was more an expression of their hatred for war, and the wish to find the type of defence that would preserve the environment and the population, than a theoretically developed idea. This idea was recalled after World War II, especially in the Cold War years. In 1964, the first international conference devoted to the idea of civilian resistance took place in Oxford. Soon the academic studies analysing the perspectives of civilian defence were published in Western Europe ${ }^{12}$. The prominent expert of military strategy Basil Liddell-Hart analyzed the defence strategy under the possibility of nuclear war. He emphasized that in the contemporary populous Europe of big cities the fight against occupation cannot be guerrilla war: it has to be non-military defence ${ }^{13}$. The German brothers Hans-Heinrich Nolte and Wilhelm Nolte have created the concept of autonomic defence. The idea was that a country in the presence of nuclear threat has to rely on its own forces, and not on the systems of the collective defence. They especially emphasised that the system of autonomic defence has to take into account the characteristics of the particular state, and combine ingeniously the military and civilian defences ${ }^{14}$. The idea of the autonomic defence was well accepted among the military and political elite of some European, mostly small, states. It was mentioned in the military doctrines of Belgium, the Netherlands, Sweden, France and Switzerland ${ }^{15}$.

\footnotetext{
${ }^{11}$ On Gandhi's ideas of civilian defence see Sharp G., Gandhi as a Political Strategist, with Essays on Ethics and Politics, Mass.: Porter Sargent, 1979.

${ }_{12}$ Adam Roberts (editor), The Strategy of Civilian Defence: Non-violent Resistance to Aggression (London: Faber and Faber, 1967), Anders Boserup and Andrew Mack, War Without Weapons: Nonviolence in National Defence (London: Frances Pinter, 1974); Gustaaf Geeraerts (editor), Possibilities of Civilian Defence in Western Europe (Amsterdam: Swets and Zeitlinger, 1977; Gene Sharp, Making Europe Unconquerable: The Potential of Civilian-based Deterrence and Defense (Cambridge, Mass.: Ballinger, 1985).

${ }^{13}$ Liddel-Hart B., Strategy. The Indirect Approach, London: Faber \& Faber Ldt., 4 th revised and further enlarged ed., 1967; Liddell-Hart, B., "Lessons from Resistance Movements, Guerrilla and Non-Violence" in Roberts 1967 (note 4) p.208-210.

${ }^{14}$ Nolte H.H \& Nolte W., Ziviler Widerstand und Autonome Abwehr, Baden-Baden, 1984, p.154.

${ }^{15}$ In 1972 the government of Sweden asked Adam Roberts to prepare the study "Total Defence and the Civilian Resistance", which made a great impact on the understanding of the national security in many Western European countries. See Niezing (note 2) p.27-30.
} 
The collapse of the Soviet Union and the end of the Cold War gave new impetus for the development of ideas on civilian defence ${ }^{16}$. Especially important for the development of the theory of civilian defence was a peaceful liberation of the Eastern Central European countries in 1989-1991 ${ }^{17}$. Lithuania had played an exceptional role here. She successfully used civilian resistance in the struggle for independence, and officially defined it as a way of state defence (in 1990-1991) ${ }^{18}$. Besides, she has not abandoned this idea since the state gained its sovereignty; instead, she gave it a significant role in the Basics of National Security of Lithuania (BNS) and in the National Security Strategy of Lithuania (NSS).

It is possible to conclude, referring to the official documents, that the main idea of Lithuania's defence is a principle of total unconditional defence. It includes both the military and non-military (civilian resistance) forms of defence. The question arises whether the ideas of total defence and civilian resistance are compatible with the new circumstances of the near future: How will these ideas exist with Lithuanian membership in NATO and the EU and its integration into a system of collective security? In trying to answer this question, this article first makes a short review of the theoretical development of the civilian defence idea, and analyses some peculiarities of its implementation in the Lithuanian liberation movement (1990-1991). Next, there is an analysis of the way civilian defence and civilian resistance is conceived in the documents defining Lithuania's security and defence policies. Finally, an attempt is made at identifying the role and tendencies of civilian resistance within the contemporary security system of Lithuania.

\section{The Concept of Civilian Defence}

The theorization on civilian defence has two traditions: pacific (principled) and pragmatic ${ }^{19}$. The first one approaches civilian defence as an alternative to military defence. It emphasizes the incompatibility of the military and pacifistic strategies. A concept of pacific defence is justified by moral arguments: first, violence as the way

${ }^{16}$ See Sharp G., Civilian-Based Defense: A Post-Military Weapons System, Princeton: Princeton University Press, 1990; Anderson S., Larmore J., ed., Nonviolent Struggle and Social Defence, London: War Resisters International, 1991; Brian M., Social Defence, Social Change, London: Freedom Press, 1993; Ackerman P., Kruegler Ch., Strategic Nonviolent Conflict: The Dynamics of People Power in the Twentieth Century, Westport: Praeger Publishers, 1994; Burrowes R.J. The Strategy of Nonviolence Defense: A Gandhian Approach, Albany, NY: State University of New York Press, 1996;. Powers, R S.,William B., eds., Protest, Power, and Change: An Encyclopedia of Nonviolent Action, New York: Garland Publishing, 1997; Ackerman, P.,Duvall J., A Force More Powerful: A Century of Non-Violent Conflict, New York: St. Martin's Press, 2000.

17 See Roberts A., Civil Resistance in the East European and Soviet Revolutions, Cambridge, MA: The Albert Einstein Institution, Monograph Series 4, 1991;

T. Bleiker R., Nonviolent Struggle and the Revolution in East Germany, Cambridge, MA: The Albert Einstein Institution, Monograph Series 6, 1993; Eglitis, O., Nonviolent Action in the Liberation of Latvia, Cambridge, MA: Albert Einstein Institution, 1993; Lieven A., The Baltic Revolution; Estonia, Latvia, Lithuania and the Path to Independence, New Haven and London:Yale University Press, 1993.

${ }^{18}$ Miniotaite, G., Nonviolent Resistance of Lithuania: A Story of Peaceful Liberation. Monograph series No. 8. Boston: Albert Einstein Institution, 2002.

${ }^{19}$ About the principled and pragmatic non-violence see Holms R., ed., Nonviolence in Theory and

Practice, Belmont, California: Wadsworth Publishing Company, 1990, p.1-6. 
to solve conflicts is unjustified by any, even the noblest, goals. The second tradition explains the requirement not to use violence with the pragmatic arguments (social, political, economical etc) - civilian defence is used not because it is more moral than other forms of defence, but because, in some circumstances, it is more efficient than military defence. The pragmatic interpretation treats civilian defence as the constituent part of total defence, as a supplement to military defence.

Civilian defence as an alternative to the military one does not exist in any country. The elements of the pragmatically interpreted civilian defence are part of the defence conceptions of some states. It is not a very big surprise that the strategy studies on civilian defence are mostly developed in a framework of the pragmatic approach. So, how do we create the defence theory that does not refer to any particular reality? Perhaps in this case we should talk about the creation of the hypothetical theory, the empirical justification of which is the historical analysis of experiences of non-violent struggles, especially related to the resistance of occupation and dictatorship. The thoughts of the classic military strategists Carl von Clausewitz and Sun Tzu are used as the theoretical basis for the new understanding of the defence. Also, some ideas of contemporary military strategists such as Stephen King-Hall and LiddellHart have been applied ${ }^{20}$.

Among works analysing the experience of non-violent resistance in the history of political and social conflicts ${ }^{21}$, the three-volume study by Gene Sharp, The Politics of Nonviolent Action (1973), has been the most distinguished ${ }^{22}$. Sharp described 198 methods of non-violent action and formulated the basic principles of its dynamic. He defines non-violent action as, "a technique used to control, combat and destroy the opponent's power by non-violent means of wielding power"23. In the definition of nonviolent action Sharp distances from the broad meaning of violence, when it is defined as everything that suppresses the development of the physical and spiritual potency of a human being: violence is related only to whose actions and forms of behaviour threaten human life. Accordingly, the non-violent struggle prohibits physical violence, but does not refuse to use other types of pressure against the opponent $\mathrm{t}^{24}$.

The politics of non-violent action are supported by a particular understanding of power. According to Sharp, political power can hold its power through the internal sources of society: these are authority, human resources, skills and knowledge, intangible factors, material resources and sanctions ${ }^{25}$. These "sources" can effectively "feed" the government until the citizens obey and cooperate. If the people cease

\footnotetext{
${ }^{20}$ See King-Hall S., Defence in the Nuclear Age, London: Victor Gollancz, 1958. In this book Stephen King-Hall recommended to abandon the nuclear weapons in Great Britain and to develop the civilian defence. Also see Liddell-Hart (note 5).

${ }^{21}$ The most popular examples are the German fight against the Belgian and French occupation in 1923, the Indian fight for independence, the non-violent resistance against the Nazi occupation in Western Europe, the opposition to the Algerian revolt of generals in 1961, the Czech resistance to the Soviet invasion in 1968, the failure of Marcos dictatorship in Philippines in 1986, Palestinian intifada in 1987-1993, the collapse of the communist regimes in Central and Eastern Europe in 1989.

${ }^{22}$ Sharp, G. The Politics of Nonviolent Action, Boston:Porter Sargent Publishers, 1973. The studies by the American professor Gene Sharp have received a broad international recognition, they have been translated into more than 30 languages, including Lithuanian, Latvian, Estonian, Russian.

${ }^{23}$ Sharp (note 22), part I, p.4.
} 
supporting the government they can control and even destroy it with non-violent means. "If they do this in sufficient numbers for long enough, that government or hierarchical system will no longer have power. This is the basic political assumption of non-violent action"26 . The notion of power as dependent upon the good will of people was applied by Mahatma Gandhi. In 1920 he wrote: "I believe, and everybody must grant, that no Government can exist for a single moment without the co-operation of the people, willing or forced, and if people suddenly withdraw their cooperation in every detail, the Government will come to a standstill' 27 . Later, Hannah Arendt emphasized that real power always comes from the people gathering together in the movements: "the people lend their power and support to the government by agreeing to act according to its rules" 28 . Kenneth Boulding in his analysis of power defined it as "integrative power". This is, "the most fundamental form of power...the power of legitimacy, respect, loyalty, affection, love and so on"29.

Sharp defined civilian defence as, "defence by civilians (as distinct from military personnel), using civilian means of struggle (as distinct from military or paramilitary means)" 30 . This is, "a projected refinement of the general technique of nonviolent action... an attempt deliberately to adapt and develop that technique to meet defence needs" 31 . According to Robert Burrowes, the strategic goal of the defence is, "to consolidate the power and will of the defending population to resist the aggression... to alter the will of the opponent elite to conduct the aggression, and to undermine their power to do so" 32 . Two types of the fight converge in this process: the defence (the alteration of opponents' will) and the offence - if the opponents do not alter their will, they can be forced to do this by the non-violent actions that are considered as "the weapons" for the civilian defence.

The "weapons" of non-violent action are divided into three broad categories:

1. Non-violent protest and persuasion (demonstrations, pickets, protest meetings, public lectures and discussions, etc);

2.Non-cooperation, which "involves the deliberate discontinuance, restriction, withholding or defiance of certain existing relationships - social, economic or political"33 (strikes, boycotts, non-tollage, electoral and judicial boycotts, civilian disobedience);

3. Non-violent intervention - "disruption or destruction of behavioural patterns, policies, relationships, or institutions that are considered unacceptable ${ }^{\text {"34 }}$ (non-

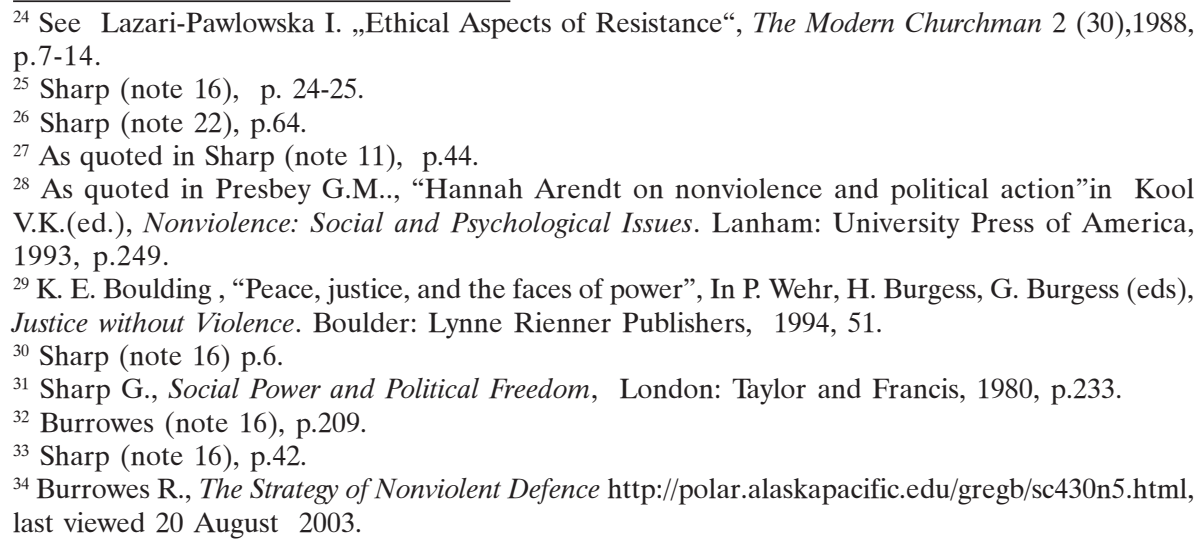


violent blockades and occupations, fasting, seeking imprisonment, establishing alternative political, economic, and social institutions, alternative schools, energy exchange cooperatives, parallel media, communications and transport networks).

Civilian defence being the "defence by civilians" requires special preparation of the population and strategic creativity of leaders. Unarmed defence against the armed opponent requires the unity of the population, a developed civil society, the personal courage of the participants, the non-violent discipline (i.e. not to respond with violence to the repressions) and the competence to reveal and exploit the vulnerable spots of the opponent. Besides, there is a special relationship with the opponent here: the civil defence does not seek to de-humanize opponents, instead the goal is to neutralize their hostility and in case of success to turn them to allies.

This short review of the civilian defence theory can make the impression that the theoreticians of the civilian defence are creating a utopian theory of a utopian world. How real is the implementation of civilian defence? First of all, we cannot forget that military defence has thousands years of history: the preservation of statehood has always been conceptualised in military terms whereas the idea of civilian defence is only several decades old. The theoreticians of civilian defence, especially those of the pragmatic approach, are making only first steps in rationalizing the idea. According to them, the move from the theory to its practical implementation has to begin from the top: introducing some elements of civilian defence into the system of national defence. In the eighties, the representatives of some European governments endorsed the usefulness of such a process. In 1986, the parliament of Sweden approved the establishment of the Commission on Non-military Resistance and, in 1990, Defence Minister Johan Holst of Norway stated: "civilian-based defence has the potential of constituting an important complement to traditional military forms of resistance" 35 . Lithuanian political elites try to put this idea into practice: they give to civilian resistance an important role in the security and defence system of Lithuania.

\section{Non-violent action and civilian defense in the Liberation of Lithuania: 1988-1991}

Many publications analyzing the collapse of the USSR have pointed out that Lithuania played the catalyst's role in the process of the disintegration of the Soviet Union. The collapse of the empire was a complex process that was influenced by a multitude of internal and external factors. Most of the authors analyzing the collapse of the Soviet empire have noticed its peacefulness ${ }^{36}$; however, the comprehensive analysis of this process from the view of the non-violent action theory still waits for its

\footnotetext{
${ }^{35}$ Holst J.J., Civilian-Based Defence in a New Era, Cambridge, Mass.: Albert Einstein Institution, Monograph Series No 2, 1990, pp. 14-15.

${ }^{36}$ See Lieven A., The Baltic Revolution: Estonia, Latvia, Lithuania and the Path to Independence, New Haven and London: Yale University Press, 1993; Smith G., ed., Baltic States: National SelfDetermination of Estonia, Latvia and Lithuania , London: Macmillan, 1994; Gerner K., Hedlund S., Baltic States and the End of the Soviet Empire, London: Routledge, 1993; Eglitis D. S., Imagining the Nation: History, Modernity and the Revolution in Latvia, Pennsylvania: The Pennsylvania state university press, 2002.
} 
researchers. The non-violent resistance in Lithuania from 1988-1991 played an important role in the struggle for independence. This period can be divided into two stages: the first begins with the establishment of Sajūdis (Movement) in 1988 (which ended March 11, 1990 when independence was declared); the second stage lasted until Lithuania was accepted to the UN on September 17, 1991. The spontaneous use of methods of non-violent action against Vilnius and Moscownomenklatura was typical for the first stage. During the second stage, the fight was directed against the Soviet military and political nomenklatura in order to preserve and consolidate the declared independence. During this period an application of projected and considerate techniques of non-violent action in the defence of independence had emerged. It has laid the foundations for an implementation of some rudiments of civilian defence into the security and defence system of Lithuania.

Lithuania was the first republic of the Soviet Union that unilaterally declared their independence. On March 11, 1990, a mere 1,5\% of the Soviet population inhabiting only $0,3 \%$ of Soviet territory - posed a fundamental challenge to the vast empire and its powerful apparatus of repression. After a few days the Extraordinary USSR Congress of the People's Deputies declared the Lithuanian independence declaration illegal and demanded "to restore the order and legitimacy"in the territory of Lithuania. From the point of view of the USSR, all further actions of Lithuania directed to the reestablishment of independence were illegal. Looking from the theory of non-violent action, these actions could be called civilian disobedience. And from the point of view of Lithuania, this was the defence and consolidation of the statehood. In the response letter the Chairman of the Supreme Council of Lithuania (SC) Vytautas Landsbergis emphasized that the resolutions of the foreign state do not have legal force in Lithuania, and the legitimate interests of the USSR could be the object of the negotiations. Both sides thought the truth was on their side and consistently sought to realize their goals. The essential difference was that the Lithuanian government had the prevailing support of the Lithuanian population, whereas the government of the USSR could rely mainly on its repressive machinery.

After the declaration of independence, the Soviet Union started a policy of intimidation: there were threats to destroy the economy, take over the territory, polarize the society, etc. The Lithuanian government proposed the negotiations and, disregarding the threats, formed institutions strengthening state sovereignty. The Law on Certification Cards was adopted, the border delimitation and control was started and the Department of National Defence was established. Moscow responded with economic sanctions, the occupation and destruction of key facilities and a roundup of the young men boycotting the conscription law. In January 1991, with the support of paratroopers and tanks, it tried to retrieve the obedience of Lithuania. Although the Press Centre, Radio and Television building and Television Transmission Tower were brutally occupied, the goal written down in Gorbachev's telegram to the Lithuanian SC - "immediately and completely re-establish the validity of the constitutions of the USSR and the Lithuanian SSR, and revoke the anti-constitutional acts which have been adopted“37 - was not achieved. On the night of January 13, 1991 the unarmed people stopped the tanks and rendered an abortive coup ${ }^{38}$.

${ }^{37}$ Lithuania, 1991.01.13: Documents, Testimonies, Comments, Vilnius: State Publishing Center, 1992, p.23.

${ }^{38}$ That night 13 people died and 702 were injured defending the Television transmission tower. See Ibidem, p.367. 
Challenging the empire, the Lithuanian SC and the Sajudis, from the beginning, chose the non-traditional un-armed forms of struggle and most often already proved methods of non-violent action. The growing danger of military aggression strengthened the understanding that the only counterweight to it can be the „Gandhi way". In December 1990 the joined conference of the SC deputies, the representatives of the local governments, and the Sajudis' Seimas declared the address "The Republic is in Danger!". The address invited all people of Lithuania "to follow the principles of disobedience and non-cooperation with the occupational institutions" ${ }^{\prime 39}$. On January 8, 1991 when the Moscow aggression seemed unavoidable, Landsbergis made an appeal to the Lithuanian people on the radio: "Come and help your own government, otherwise a foreign one will overcome us" ${ }^{40}$. The TV showed the movie by Richard Attenborough „Gandhi“. The permanent watch of Lithuanian people near Seimas, the Press Centre, and the Television Transmission Tower organised by Sajudis was started. The unarmed policemen, and undergraduates of the Academy of the Police, joined the watch with the main task of preventing armed confrontations.

The January events in Lithuania, and also in Latvia ${ }^{41}$, did not come up to the expectations of Moscow. The Supreme Council, the Council of Ministers and the local governments kept control in the cities. Lithuanian police stayed faithful to the Republic of Lithuania. The authority and the support to the government grew considerably. The use of violence against the peaceful population has lead to the so-called "political jujitsu". This is the situation when after the violence has been used the number of resisting people and the disobedience of the population grow, frictions among the opponents show up, and the possibilities to break the disobedience and so to continue the intended politics are diminishing ${ }^{42}$. According to the British journalist Anatol Lieven, "Soviet measures however only increased the determination and morale of ordinary Lithuanians. Those who, immediately after declaration [of independence], had been critical of Landsbergis and Sajudis, became increasingly supportive, and popular demonstrations returned to their pre-independence dimensions" ${ }^{\prime 3}$. Besides, after the January events the support of the population of the Soviet Union and other countries for Lithuania had also strengthened.

The January events in Lithuania manifested the efficiency of unarmed defence: the civilian population defended objects very important to Lithuanian independencethe Supreme Council and the Television station in Sitkunai that later gave the possibility to renew television broadcasting. So, it was not an accident that the support of the Lithuanian government and its society for civilian defence has strengthened after the January events. The government viewed civilian defence as a matter of calculated organization, not merely a spontaneous outburst of people power. As the resolution of the SC dated February 28 stated:

${ }^{39}$ Landsbergis V., Laisvés byla, Vilnius: Lietuvos Aidas, 1992, p.182.

${ }^{40}$ Ibid, p.186.

${ }^{41}$ See Eglitis O., Nonviolent Action in the Liberation of Latvia, Cambridhe, MA: Albert Einstein Institution, 1993, pp. 31-35.

${ }^{42}$ On the concept of the political jujitsu see Sharp (note 16) pp. 58-60.

${ }^{43}$ Lieven (note 36), p.239. This was also supported by the survey made on January 14, 1991 by the Laboratory of Sociology of Vilnius University and Public Opinion Research Centre of the Lithuanian Academy of Sciences. The survey showed that support for the Lithuanian independence has increased even among the non-Lithuanians living in Lithuania, especially Russians. See Lietuvos Aidas, January 23, 1991. 
In the event a regime of active occupation is introduced, citizens of the Republic of Lithuania are asked to adhere to principles of disobedience, non-violent resistance, and political and social non-cooperation as the primary means of struggle for independence ${ }^{44}$

The resolution was due both to practical experience and to theoretical insights provided by Gene Sharp's book Civilian-Based Defence ${ }^{45}$. In the beginning, some elements of civilian defence had tried to be implemented in order to deter the Soviet aggression. They were tried to persuade the Soviet political and military elite that their goal - to fight Lithuania back with force - was unreachable, and the attempt to do this would only bring the huge material and moral loss to perestroika and to international prestige of the state. The Department of National Defence began to publish the newspaper, in Russian, Doroga Litvy (Lithuanian Way) as early as January 1991. The newspaper was distributed among Soviet military personnel serving in both Lithuania and the Soviet Union. The material about the January events was also multiplied and distributed. Sajūdis and the deputies of the Supreme Council kept close relations with the national liberation movements throughout the Soviet Union, trying to influence the process of democratisation ${ }^{46}$.

The important task was the education of the population and the military, their preparation to use the "weapons" of civilian defence - the techniques of non-violent action. "This is the non-traditional weapon system, which has to be learned to manipulate. It requires much more knowledge, intellect, understanding of human nature than the usual gun or the stick of the policeman", - Audrius Butkevicius, the minister of National Defence, wrote on the occasion of the publication of Sharp's book in Lithuanian ${ }^{47}$. The Commission of the Psychological Defence and Civilian Resistance was created on a decree by the government in February 1991. The decree provisioned to "prepare the instruction on civilian resistance for the staff of the KAD [Department of National Defence] and the volunteers SKAT [Voluntary Country Defence Service]... organise the training of the volunteers in accordance to the programmes of the non-violent resistance"48. The Voluntary Country Defence Service paid great attention to the organisation of the volunteer training by supporting the translation of related literature into Lithuanian ${ }^{49}$. In order to indoctrinate the population the main Lithuanian newspapers published material on the history and methods of civilian resistance. TV shows presenting to the people the main principles of civilian defence were also broadcasted.

${ }^{44}$ Lietuvos Respublikos Aukščiausios tarybos ir vyriausybès žinios, 1991, t.8, p.324. [Lithuanian Supreme Council and Government News].

${ }^{45}$ The Sharp's book Civilian-Based Defence (1990) was translated into Lithuanian already at the end of 1990s. The manuscript of the translation was intently studied by the director of the Department of National Defence, other officers, the activists of Sajudis. The other book by Sharp SelfReliant Defense without Bankruptcy or War (1990) was also translated into the Lithuanian and published in 1992.

${ }^{46}$ In Lithuania, after the strikes of the Donetsk amd Kuznetsk miners had started, the food was being collected for the strikers on the initiative of the Labour Union. The shipment of the support by lorries through the Soviet Union had a very huge ideological meaning: together with the food the positive information about Lithuania has also travelled.

47 Sharpas, G., Pilietine gynyba: postmilitariniu ginkly sistema, Vilnius: Mintis, 1992, p.147.

${ }^{48}$ Krašto apsaugos departamento isakymas Nr.12, February 20, 1991 [Decree of the Department of National Defence], Author's archive.

${ }^{49}$ The chapters from the books about the experience of the non-violent resistance of Finland, India, Norway, Philippines, Polish Solidarno ${ }^{-}$ę were translated. The article "The Role of Power in Nonviolent Struggle” by Sharp was published in Library of the Volunteer. See: „Jègos vaidmuo nesmurtinèje kovoje", Savanorio bibliotekèle, 1991, 3. 
When the putsch started in Moscow on August 19, 1991, Landsbergis insisted: "the main resistance of Lithuania in case of occupation is the unarmed non-violent resistance" $"{ }^{50}$. Lithuanian people again were invited to gather near the building of the SC. The Department of National Defence issued the decree that obliged the staff of the national defence system in case of occupation to "organise and implement the actions of the civilian resistance in whole territory of the Republic of Lithuania using the techniques of the non-violent resistance" ${ }^{51}$. Soonafter the putschists lost in Moscow, Lithuania received international recognition. It became a member of the UN on September 17, 1991.

This short review of the Lithuanian liberation struggle of 1988-1991 proves the efficiency of non-violent resistance and shows its perspectives in state defence. However, it would be very naive to explain the achieved independence only through the strategy of non-violent resistance. The Lithuanian Independence was declared under especially favourable internal as well as external circumstances. Perestroika in the Soviet Union opened the way to publicity and democratisation, and started to destroy the fundamentals of the totalitarian regime. The victory of the Solidarity in Poland, the "velvet" revolution in Czechoslovakia and the unification of Germany created a very favourable international environment for the liberation movements in the Baltic States. During a few years Lithuania, as well as the other Baltic States, accumulated valuable experience of non-violent resistance. In addition, the independent power structures were formed providing for the liberation movement the necessary direction and normative justification. The declaration of independence created a unique situation where the goals of the new power and of the Lithuanian society coincided. Besides, the determination of the population to keep the non-violent discipline, resisting the opponent's provocations to respond to violence with violence, helped gain the support of world pubic opinion to Lithuania. The independence was achieved with the minimal number of victims; the resources and the infrastructure of the country were preserved.

\section{Civilian resistance in the Security and Defence System of the contemporary Lithuania}

After international recognition, Lithuania started developing its independent domestic and foreign policy; which as guidance chose, by the theory of the small state asserting: "a small state's foreign policy must first of all deal with the potential threat posted by great powers in order to secure its own survival ${ }^{\prime 52}$. Seeing the main threat in the "unstable and unpredictable" Russia, Lithuania gradually turned away from the idea of a country being a bridge between East and West to closer cooperation with the West. This trend strengthened after the withdrawal of Russian troops from Lithuania in 1993. The consistent implementation of the Western direction in politics led Lithuania to membership in NATO and the EU. The question arises: how is the

\footnotetext{
${ }^{50}$ Landsbergis (note 39) p.284.

${ }^{51}$ Krašto apsaugos departamento įsakymas Nr. 160, August 18, 1991 (Author's archive). [Decree of the Department of National Defence]

${ }^{52}$ Knudsen O.F. "Baltic States' Foreign Policies," Nordic Journal of International Studies, 28 (1) , March 1993, p. 48.
} 
experience of non-violent resistance, which played a prominent role in seeking the recognition of independence, reflected in the contemporary security and defence politics of Lithuania? Is the idea of civilian defence compatible with Lithuania's participation in the system of collective security, its membership in NATO and the EU? I will try to answer this question by reviewing the conceptualization of the Lithuanian security and defence politics.

The security of the state and the nation has been the main topic of Lithuanian political discourse from the first days of the independence declaration. Already in 1992, the first draft of the national security conception was prepared. It paid much attention to civilian defence $^{53}$. During the same year the Ministry of National Defence, in cooperation with the Albert Einstein Institution (USA), organised the international conference on the application and perspectives of the civilian defence in the Baltic States. In 1992 the educational unit of the Department of Civil Security instituted training courses on the subject. The nongovernmental organisation The Centre for Non-violent Action that was established in 1991 also engaged in the educational and academic activities. Later, The Civilian Resistance Training Division at the Adolfas Ramanauskas Servicemen's Vocational Training Centre of the Ministry of Defence started its activity. The short introduction to civilian resistance basics was lectured to officers of the Ministry of National Defence and other related institutions $^{54}$. In 1995 the draft agreement between Lithuania, Latvia, and Estonia on the cooperation in civilian defence was prepared ${ }^{55}$. Although all countries agreed on this idea, the agreement has not yet been signed. The approaching membership in NATO diminished the attention paid to civilian defence, especially in Latvia and Estonia.

At the end of 1996 Seimas adopted the Law on the Basics of National Security of Lithuania (BNS) that provided the solid legal grounding to civilian resistance. Civilian defence is the essential part of civilian resistance. In section 7.4 (Civilian resistance) of the document it is written:

The power of civil resistance is determined by the will of the Nation and selfdetermination to fight for its own freedom, by each citizen's resolve, irrespective of age and profession, to resist the assailant or invader by all possible means and to contribute to Lithuania's defence.

The system of citizens' preparedness for civil resistance shall be raised to the national level. Its functioning shall be organized by the Government.

In the event of assault or attempt to violate Lithuania's territorial integrity or its constitutional order, the citizens and their self-activated structures shall undertake actions of civil resistance - non-violent resistance, disobedience and non-collaboration with the unlawful administration, as well as armed resistance..$^{56}$

\footnotetext{
${ }^{53}$ See: "Lietuvos respublikos nacionalinio saugumo koncepcija. Projektas, 1992" [The conception of National Security of the Republic of Lithuania. Draft]; Bagdonavičius V., ed., Lietuvos nacionalinis saugumas: teorija ir realijos, Vilnius: Filosofijos, sociologijos ir teisès institutas, 1994, pp.125145 [Lithuanian National Security: Theory and Reality].

${ }^{54}$ In the beginning the participants of the course were the members of the Association of Servicemen of Active Reserve, the leaders of the Scout Union, the commanders of the Riflemen's Union and the public relations officers of the military troops. See Mankevičius V. and Daugirdas A., Pilietinis pasipriešinimas, Vilnius: Mažoji Evelina, 2002, p.3.

55 The impetus for the treaty arose from a 1992 conference in Vilnius attended by representatives of Lithuanian, Latvian, Estonian, and Swedish ministries of defence, together with international scholars. 56 "Lietuvos respublikos nacionalinio saugumo pagrindų įstatymas," Valstybés žinios, 1997, No. 2, pp. 2-20. [Law on the Basics of National Security of Lithuania].
} 
The provisions on the civilian resistance are also included into the National Security Strategy (2002) and the National Defence Strategy (2000) ${ }^{57}$. The Lithuanian government implementing the Law on the Basics of National Security established The State Civilian Resistance Training Centre at the Ministry of National Defence in 2000. Its goal is "to train and prepare the citizens for individual and organised civil resistance and civilian defence directly and through co-ordination of the activities of other institutions" ${ }^{\prime 58}$. The Centre started its work in 2001. It continues the activities of the Civilian Resistance Training Division.

The review on the implementation of the idea of the civilian resistance in Lithuania during the independence period shows that some elements of civilian defence have been included into the main documents of Lithuanian security and defence policy. "Total preparations of the citizens to the resistance" (BNS) plays a significant role in the deterrence of any "potential aggressor". However, these preparations, which are mainly educational, are not covering the whole population; mainly they are directed to the institutions linked with the Ministry of National Defence. According to the programme, the activity of The Civilian Resistance Training Centre has to be addressed to a broader audience. It has to cooperate closely with the scholarly and educational institutions, the Church, local authorities and non-governmental organisations.

Civilian resistance is important not only in the deterrence of aggression, but also in the defence. The "Total and unconditional defence" model of Lithuania is comparable to Switzerland's strategic triad of the total defence (Gesamptverteidigung) of the1980's, which was composed of military defence, guerrilla warfare, and non-military defence ${ }^{59}$. Almost the same components are included in the Basics of National Security: Lithuania "shall seek to deter any potential assailant" by the means of military defence and civilian resistance, which encompasses guerrilla warfare and "the actions of the non-violent resistance". The civilian resistance should begin after the military defence has been suspended and the aggressor has occupied the country. The essential question of the civilian resistance strategy arises in this defence stage - are armed guerrilla warfare and non-violent civilian defence compatible? The studies on civilian defence assert almost unanimously that a defence where military action and non-violent resistance are simultaneously used is doomed to failure. Such defence destroys the raison d'etre of the effectiveness of civilian resistance - the moral superiority of those who are resisting, which is very important when seeking a positive international reac-

\footnotetext{
${ }^{57}$ Nacionalinio saugumo strategija [The National Security Strategy] http://www.kam.lt/catalog/ ministerija/nacionalinio_saugumo_strategija_06_05.doc; Nacionalinès gynybos strategija [The National Defence Strategy]

http://www.kam.is.lt/index.php?ItemId=9675, last viewed 10 August 2003.

${ }^{58}$ Nutarimas dèl Valstybinio pilietinio pasipriešinimo rengimo centro prie Krašto apsaugos ministerijos îsteigimo 200011 07, Nr. 1359, Valstybès žinios, 98, 2000, p. 73. (Decree on the establishment of the State Civilian Resistance Training Centre at the Ministry of Defence).

${ }^{59}$ See: Nizing, (note 9) p.29.
} 
tion. Besides, military violence is concurrent with civilian casualties and destruction of the environment and these give reason to justify the repressions $s^{60}$. Beyond any doubts, the further development of civilian resistance requires a more comprehensive theoretical reasoning: the analysis of the relationship between the military and non-military strategies of defence and studies on the social and political conditions that are necessary to implement this unconventional form of defence ${ }^{61}$.

The inclusion of civilian resistance into the security and defence system of Lithuania is a sequel of the principle of total and unconditional defence which commits "each and every citizen to resist aggression by all means possible" (NSS, 6.3.4). Thus an answer to the question of whether the emphasis on civilian resistance in Lithuania's defence system is a well-timed one depends on an answer to the question of whether the principle of total and unconditional defence is a well-timed one. The adoption of the strategy of total and unconditional defence by Lithuania's political elite was the result of many different factors, the most important of which was probably a specific interpretation of Lithuania's interwar history. The interpretation was a kind of polemics of the present with the painful events of 1940, when Lithuania, though militarized, made no attempt at resisting the Soviet Union ultimatum. Presumably, the commitment to total and unconditional resistance should prevent the repetition of such surrender. The choice of total defence was also influenced by the predominance in Lithuania's political discourse of the neorealist interpretation of her geopolitical environment and by the modernist conception of sovereignty. The experience of neighboring countries, particularly Sweden, has also played a role.

The official documents referred to in this paper show no explicit doubts as to whether membership in NATO and the EU would guarantee Lithuania's territorial security; however, since ,the global dynamic developments will present new challenges, dangerous conditions and threats" (NSS, 7.3), total civilian resistance is still considered a universal response to potential threats.

\section{Concluding remarks}

Just after the recognition of Lithuania's independence, with the country's first steps of setting up its national security system, many theoreticians and enthusiasts of civilian defense cherished the hope that Lithuania would become the first country in the world having its security system based on the ideas and methods of non-military civilian resistance. One cannot say that Lithuania has totally failed to live up to their expectations, for elements of civilian-based defense have indeed been included in its security and defense policies. It is to be noted that even though all Eastern and Central European countries have experienced the efficiency of non-violent struggle, Lit-

${ }^{60}$ See: Низинг ( note 2); Sharp ( note 18), and Ackerman ( note 8). The same point was made by former minister of National Defence Butkevicius: „After the state has shifted to a civilian-based mode of resistance, it would need to view the organizers of continued resistance violence as possible provocateurs serving the aggressor, for their actions would undermine the defence effort. The state must explicitly declare its defence policy during the occupation to be civilian-based defence. See Butkevicius A, Theses on the Defense Strategy of Small States, Cambridge, MA: The Albert Einstein Institution, 1994, photocopy, p. 26. See also Sharp (note 16), p. 39.

${ }^{61}$ See Gilliam de Valk in cooperation with Johan Niezing, Research on Civilian-Based Defence, Amsterdam: SISWO, 1993. 
huania alone has officially recognized its viability. The role accorded to civilian resistance in documents representing Lithuania's security and defense policies is quite unique in defense conceptualizations currently predominant in the world.

Having briefly surveyed the story of the emergence of the idea of civilianbased defense and of its taking some hold in Lithuania, I won't attempt any prophesies about its future, but confine myself to noting some tendencies and problems relating to its development in the post-Cold War era.

The theory of civilian defense was fleshed out in the Cold War period mostly in small, non-nuclear countries. The conceptual basis of both civilian and military defense has always been, and still remains, that of the neorealist conception of the international system. Neorealism conceives security in terms of geopolitically determined and constant threats to the state and to the nation, threats that have to be identified and neutralized by political and military means. The world is seen as divided into a secure, rationally manageable inside of the nation state and the threatening, anarchic, unpredictable outside, that is, the domains of peace and danger, respectively. This is the conception of international relations that underlies the rationale of total and unconditional defence and civilian resistance in The Basics of National Security of Lithuania ${ }^{62}$.

In the world order as it is conceived by neorealism the basis of a society's consolidation and mobilization for defence is the recognition, construction and reconstruction of common, clearly identifiable threats to its collective (national) identity $^{63}$. In Lithuania, from 1988-91, the common threat that was conceived as consolidating the society was that posed by the Soviet Union and, later on, by the "unreliable and unpredictable" Russia.

With the demise of the bipolar world order and with the intensification of global processes, the boundary line dividing the domains of peace and danger has lost much of its definiteness and became much more fluid. Democratic countries have been challenged by new common threats related to terrorism, illegal immigration, and human rights violations. The concepts of security and threat have undergone changes, for the enemy, previously so well-defined, is becoming much less clear-cut.

Lithuania's participation in the Euro-Atlantic integration strengthens its territorial security, yet at the same time it weakens the symbolic tie between the nation and the state, and is erosive of national identity. With threats becoming more diffuse, the factors that consolidate society have also been changing. The role of a common nationality in the formation of a collective identity is on the decrease. The focus for consolidation is increasingly not so much common national identity but rather a public spirit and common civil values. The "strong" national identity is being superceded by what the German philosopher Jürgen Habermas called constitutional patriotism ${ }^{64}$.

${ }^{62}$ See: Miniotaite G., „The Baltic States: In Search of Security and Identity”, in Krupnick Ch., ed., Almost NATO: Partners and Players in Central and Eastern European Security, Lanham, Md: Rowman \& Littlefield, 2003, p. 261-296.

${ }^{63}$ See: Campbell D., Writing Security: United States Foreign Policy and the Politics of Identity,

Manchester: Manchester University Press, 1993.

${ }^{64}$ Habermas J., The Inclusion of the Other: Studies in Political Theory, Cambridge, Mass.: The MIT

Press, 1998, p.225-226. 
Under these new circumstances the object of civilian resistance and civilian defence has been undergoing changes. Deterrence of aggression aimed at a concrete enemy is losing its point. The main rationale of civilian resistance at the present stage of the country's democratic development seems to be the defence of fundamental civil rights, the preservation and fostering of a strong civil society and its values. Accordingly, in a system of civilian resistance, deterrence would be transformed into an educational project of preparing people for civic life. This is the way civilian defence has been treated in Lithuania's system of defence in recent years, as it is evidenced by the program and the activities of the Civilian Resistance Training Centre. 